\title{
SOME REMARKS AND EMENDATION OF THE FAMILY ARIONOCERATIDAE DZIK 1984 (CEPHALOPODA, NAUTILOIDEA)
}

\author{
Maurizio Gnoli
}

\begin{abstract}
This paper discusses the newly proposed family Arionoceratidae Dzik 1984 at the familial, generic, and specific levels. An emendation of this family is proposed that clarifies some of this family's more characteristic features. Evidence for possible sexual dimorphism in Arionoceras submoniliforme (Meneghini 1857) is also discussed.

Maurizio Gnoli, (Dipartimento Scienze della Terra, Modena University)

Keywords: Cephalopoda, Nautiloidea, Arionoceratidae, Silurian, northern Gondwana.

Copyright: Paleontological Society, 1 August 1998

Submission: 3 February 1998, Acceptance: 2 June 1998

http://palaeo-electronica.org/1998 2/gnoli/issue2.htm
\end{abstract}

\section{INTRODUCTION}

Serpagli \& Gnoli (1977) studied representatives of the genus Arionoceras Barskov 1966 and concluded that this generic designation was valid. While originally placed in the Michelinoceratidae, Serpagli \& Gnoli (1977) attributed Arionoceras to the Geisonoceratidae Zhuravleva (1959) on the basis of the (addmittedly irregular) occurrence of a lining-like endosiphuncular deposit. Furthermore, these authors considered Orthoceras arion Barrande (type-species of the genus Arionoceras) a junior synonym of Meneghini's 1857 species $O$. affine. This revision would imply a change in the latter as the type species of Arionoceras. Serpagli \& Gnoli's (1977) taxonomic emendation was based on comparative analyses of the inner and outer features of the original types of both authors (the Meneghini specimen stored at the University of Pisa collection and the Barrande's type stored at the National Museum in Prague).

In 1984 Dzik erected the family Arionoceratidae, including Barskov's genus Arionoceras with the following diagnosis: Relatively short shell, straight to slightly curved (most commonly endogastrically) with circular cross section, and narrow, cylindrical, central siphuncle. When Dzik (1984) proposed the family Arionoceratidae it embraced the genera Arionoceras Barskov 1966, Psilorthoceras Ristedt 1968 and Caliceras Kolebaba 1975 considered as synonyms, Vericeras Kolebaba 1977 and Parakionoceras $\underline{\text { Foerste }}$ 1928. Later Engeser

(http://www.imgp.gwdg.de/tengese/nautiloidea/nautiloideafamilies/arionoceratdzik1984. htm); last change: 13 July 1997) attributed the genera Akrosphaerorthoceras Ristedt 1968, and Temperoceras Barskov 1960 to Dzik's family, but considered Caliceras and 
Psilorthoceras as valid genera. Given these recent revisions, the taxonomic identification of Dzik's family Arionoceratidae seems to be in need of revision; especially concerning which taxa do and do not belong to it.

\section{REMARKS AND FAMILY REVISION}

Arionoceras arion (Barrande 1868), A. affine (Meneghini 1857), A. canonicum (Meneghini 1857), A. densiseptum Kobayashi 1983, A. submoniliforme (Meneghini $\underline{1857})=($ Psilorthoceras procerum Ristedt 1968, P. crassum Ristedt 1968, $P$. subcrassum Ristedt 1968), A. capillosum (Barrande 1868), A. repetitum (Barrande 1870) A. septentrionale Zhuravleva 1978, A. severum (Barrande 1866), A. simplex (Desnoy in Meneghini 1857, A. canonicum (Meneghini) synonymous with $A$. affine) and A. valens (Barrande 1868) are considered to belong in the family Arionoceratidae Dzik 1984. The genera Caliceras Kolebaba and Psilorthoceras Ristedt represent synonyms of Arionoceras Barskov. Small, but detectable differences in the protoconch dimensions, angle of expansion, and a diverse septal spacing between Meneghini's 1857 species $A$. affine and $A$. submoniliforme could, perhaps, be interpreted as sexually dimorphic characters of $A$. submoniliforme. If the morphological variation in this ancient nautiloid species is interpreted in light of patterns present in modern Nautilus (the sexual dimorphism of which is due to the broader aperture of the males than that of the females) we must consider as the male's features those of $A$. submoniliforme and those of $A$. affine as the female (see also Stenzel 1964, Tanabe and Tsukahara 1987, Saunders \& Ward 1987, and Hayasaka et al. (1987). Stridsberg (1988) also argued for size variation as indicator of sexual dimorphism in the trimeroceratid Torquatoceras undulatum Stridsberg 1988, though this conslusion is currently accepted as a working hypothesis only.

The genus Akrosphaerorthoceras Ristedt 1868 bears a very little protoconch, which is a characteristic of the Family Arionoceratidae. The genus Temperoceras Barskov 1960 lacks recent studies of its apex; especially as concerns its protoconch. The arguments considered by Dzik regarding placement of the genus Parakionoceras Foerste 1928 mainly concern features of its suborthochoanitic siphuncle. On the other hand Foerste's genus seems sufficiently peculiar in characters relating to its outer ornamentationstructure to isolate Parakionoceras from the other genera. It is the opinion of the writer that the typical features of arionoceratids, besides those reported by Dzik, primarily consist of the suborthochoanitic, terminally very acuminate, and short septal necks, connecting rings slightly expanding within chambers and a big protoconch usually more than two $\mathrm{mm}$ in length, ogive-like in shape crossed by long caecum linked apicad to the beginning of the conch by a short prosiphon (see Serpagli \& Gnoli 1977, p. 183, textfigs. 10 , 11, pl. 6, figs. 2a-7, 9a-b, pl. 8, figs. 1-3, and here Fig. 1). As far as 0 . affine Meneghini 1857 (previously O. affine Portlock 1843), is concerned, as reported in the Engeser's Internet page, it must be noted that Histon (1997) and Histon \& Sevastopulo (1993) taxonomically revised this Irish Lower Carboniferous species as Mitorthoceras affine (Portlock).

To conclude, it is the opinion of this writer that at present the family Arionoceratidae 
Dzik 1984 embraces only the genus Arionoceras Barskov. Additional work in this area may include (1) further taxonomic study to increase the number of diagnostic features attributible to this genus and (2) to consider Arionoceras Barskov as belonging in Zhuravleva's Family Geisonoceratidae as already proposed by Serpagli \& Gnoli (1977) or Gnoli $(1990,1998$, in press). Finally, it is worth noting that this writer has recently had the opportunity to examine representatives of the Arionoceratidae in all the terranes or microplates [at least in: Tinduf Basin, Anti-Atlas, Mid-North Armorican Domain (bona fide Babin et al., 1979), Montagne Noire, SW Sardinia, Carnic Alps and Central Bohemia (Paris \& Robardet, 1990: Robardet et al, 1994 and Gnoli in preparation) that together constitute the northern belt of Gondwana during Silurian time.

\section{ACKNOWLEDGMENTS}

This work has benefited of English style improvements by Kathleen Histon (Austrian Geological Survey). Thanks are also due to anonymous referees for useful suggestions. The present research was funded by MURST and CNR grants (resp. Prof. E. Serpagli). 


\section{REFERENCES}

Babin C., Deunff J., Melou M., Paris F., Pelhaate A., Plusquellec Y. \& Racheboeuf P.R. 1979. La coupe de Porz ar Vouden (Prídolí de la presqu'ile de Crozon) Massif Armoricain, France, lithologie et biostratigraphie. Palaeontographica Abteilung A, 164(1-3): 52-84, Stuttgart.

Barrande J. 1865. Systéme Silurien du centre de la Bohéme. I ${ }^{\text {re }}$ Partie: Recherches Paléontologiques, v. 2, Classe des Mollusques, Ordre des Céphalopodes, 1re Série, pls. 1-107, Prague, Paris.

Barrande J. 1866. Systéme Silurien du centre de la Bohéme. I re Partie: Recherches Paléontologiques, v. 2, Classe des Mollusques, Ordre des Céphalopodes, 2me Série, pls. 108-244, Prague, Paris.

Barrande J. 1868. Systéme Silurien du centre de la Bohéme. Iére Partie: Recherches Paléontologiques, v. 2, Classe des Mollusques, Ordre des Céphalopodes, 3me Série, pls. 245-350, Prague, Paris.

Barrande J. 1870. Systéme Silurien du centre de la Bohéme. $\left.\right|^{\text {ére }}$ Partie: Recherches Paléontologiques, v. 2, Classe des Mollusques, Ordre des Céphalopodes, 4me Série, pls. 351-460, Distribution horizontale et verticale des Cephalopodes, dans le contrées siluriennes, Prague, Paris.

Barrande J. 1874. Systéme Silurien du centre de la Bohéme. I re Partie: Recherches Paléontologiques, v. 2, Classe des Mollusques, Ordre des Céphalopodes Supplément et Série tardive, pls. 461-544, Texte III, Prague, Paris.

Barrande J. 1877a. Systéme Silurien du centre de la Bohéme. $\left.\right|^{\text {re }}$ Partie: Recherches Paléontologiques, Classe des Mollusques, Ordre des Céphalopodes, Texte IV, Prague, Paris.

Barrande J. 1877b. Systéme Silurien du centre de la Bohéme. $\left.\right|^{\text {ére }}$ Partie: Recherches Paléontologiques, Classe des Mollusques, Ordre des Céphalopodes, Texte V, Prague, Paris.

Barskov I. S. 1960. Silurian and Devonian Nautiloids From South Fergany. Byulleten' Moskovskogo O'shchestra Ispytatelei Prirody Otdel Geulogishkii (4): 153., Moscow.

Barskov I. S. 1966. Golovonogie pozdneho ordovika i silura Kazachstana i Sredneji Asii [Cephalopods of Late Ordovician and Silurian of Kasachstan and Middle Asia]. Autoreferat dissertatcii na soiskanie utchenoji stepeni kandidata geol.-min. nauk. Izdatelstvo Moskovskogo Universitate. 200 pp., Moscow.

Dzik J. 1984. Phylogeny of the Nautiloidea. Palaeontologia Polonica, 45, 220 p., Warsaw.

Engeser T. 1997. Internet Electronic page

[http://www.imgp.gwdg.de/tengese/nautiloidea/nautiloideafamilies/arionoceratdzik1984.htm].

Foerste A. F. 1928. A restudies of American orthoconic Silurian cephalopods. Denison University Bullettin of Journal Science Laboratory, 23: 236-320.

Gnoli M. 1990. New evidence for faunal links between Sardinia and Bohemia in Silurian time on the basis of Nautiloids. Bollettino della Società Paleontologica Italiana, 29(3): 289-307, Modena.

Gnoli M. 1998. A further contribution towards the taxonomic revision of Silurian Nautiloid cephalopods erected and/or reported by J. Barrande in the last century in the Barrandian (Central Bohemia). Acta Universitatis Carolinae (1997) (in press), Praha.

Gnoli M. in press. Reconstruction of the northern margin of Gondwana by mean of the Cephalopod 
limestone biofacies' fauna during Silurian-Early Devonian time. (In progress)

Gnoli M. and Histon K. 1998. Silurian nautiloid cephalopods from the Carnic Alps: a preliminary investigation. Bollettino della Società Paleontologica Italiana, (1997) Vol. 36(3): 311-330, Modena.

Hayasaka S., Öki K., Tanabe K., Saisho T. and Shinomiya A. 1987. In (Saunders, K.B. \& Landman, N.H. (Eds.), On the Habitat of Nautilus pompilius in Tañon Strait (Philippines) and the Fiji Islands -

Sexual Dimorphism, pp. 197-199.

I.C.Z.N. 1985. International Code of Zoological Nomenclature, 3 edition, Ride et al. (Eds.), Huddersfield, England.

Kolebaba I. 1975. Caliceras n. gen. and ontogeny of C. capillosum (Barrande) (Nautiloidea). Casopis pro mineralogii a geologii, roc. 20, c.4, pp. 377-392, Praha.

Histon, K. 1997. Nautiloid species described from the Carboniferous of Ireland. Irish Journal of Earth Sciences, 16, (in press).

Histon K. \& Sevastopulo G. 1993. Carboniferous nautiloids and the Bathymetry of Waulsortian Limestones in Ireland. Proceeding of the Geologists' Association, 104: 149-154., Dublin.

Kolebaba I. 1977. New information on longitudinally sculptured orthceroids. Casopis pro mineralogii a geologii, roc. 22, c.2: 125-138, Praha.

Kobayashi T. 1983. On the Silurian cephalopod faunule from Mt. Yokohura, Kochi Prefecture, Shikoku, Japan. Proceeding of the Japan Academy, Series B, 59: 293-295, Kochi, Japan.

Meneghini G. 1857. Paléontologie de l'île de Sardaigne in La Marmora A., Voiage en Sardaigne: 1-584, Imprimerie Royal, Turin.

Paris F. and Robardet M. 1990. Early Paleozoic palaeobiogeography of the Variscan regions. In Matte, Ph. (ed.), Terranes in the Variscan Belt of Europe and Circum-Atlantic Paleozoic Orogens.

Tectonophysics, 177: 193-217.

Portlock J. E. 1843. Report on the geology of the county of Londonderry and parts of Tyrone and Fermanagh. 784 p., Dublin.

Ristedt, H. 1968. Zur Revision der Orthoceratidae. Akademie der Wissenschaften und der Literatur, Abandlungen der Mathematisch-Naturwissenschaftlinchen Klasse, Jahrgang 1968, 4: 213-297, Wiesbaden.

Robardet M., Verniers J., Feist R. and Paris F. 1994. The pre-Variscan Paleozoic succession in France, palaeogeographic and geodynamic setting. Geologie de la France, 3: 3-31.

Saunders, W. B. and Ward, P. D. 1987. Ecology, distribution, and population characteristics of Nautilus. Pp. 137-162, in Saunders, W. B. and Landman, N. H. (eds.) Nautilus: The Biology and paleobiology of a Living Fossil, Plenum.

Serpagli E. \& Gnoli M. 1977. Upper Silurian cephalopods from southwestern Sardinia. Bollettino della Società Paleontologica Italiana, 16(2): 153-196, Modena.

Stenzel H.B. 1964. Living Nautilus. In (Moore, R.C. Ed.), Treatise on Invertebrate Paleontology Sexual Dimorphism, pp. K74, Geological Society of America and University Kansas Press.

Stridsberg S. 1988. A Silurian cephalopod genus with a reinforced frilled shell. Palaeontology, Vol. 31, Part 3: 651-663. 
Tanabe K and Tsukahara J. 1987. In Saunders K.B. and Landman N.H. (Eds.), Biometric Analysis of Nautilus pompilius from the Philippines and the Fiji Islands - Gonad Development and Sexual

Dimorphism, pp. 111-113.

Zhuravleva F. A. 1978. Devonian Orthoceratoidea. Akademy of Sciences of the SSSR. Transaction of the Palaeontological Institute, 168: 1-224., Moscow. 
Figure 1. A. Longitudinal, schematically cross-section of Arionoceras submoniliforme (Meneghini 1857), B. The same as above of Arionoceras affine (Meneghini 1857), C. Particular enlarged of the characteristic septal neck (see text).

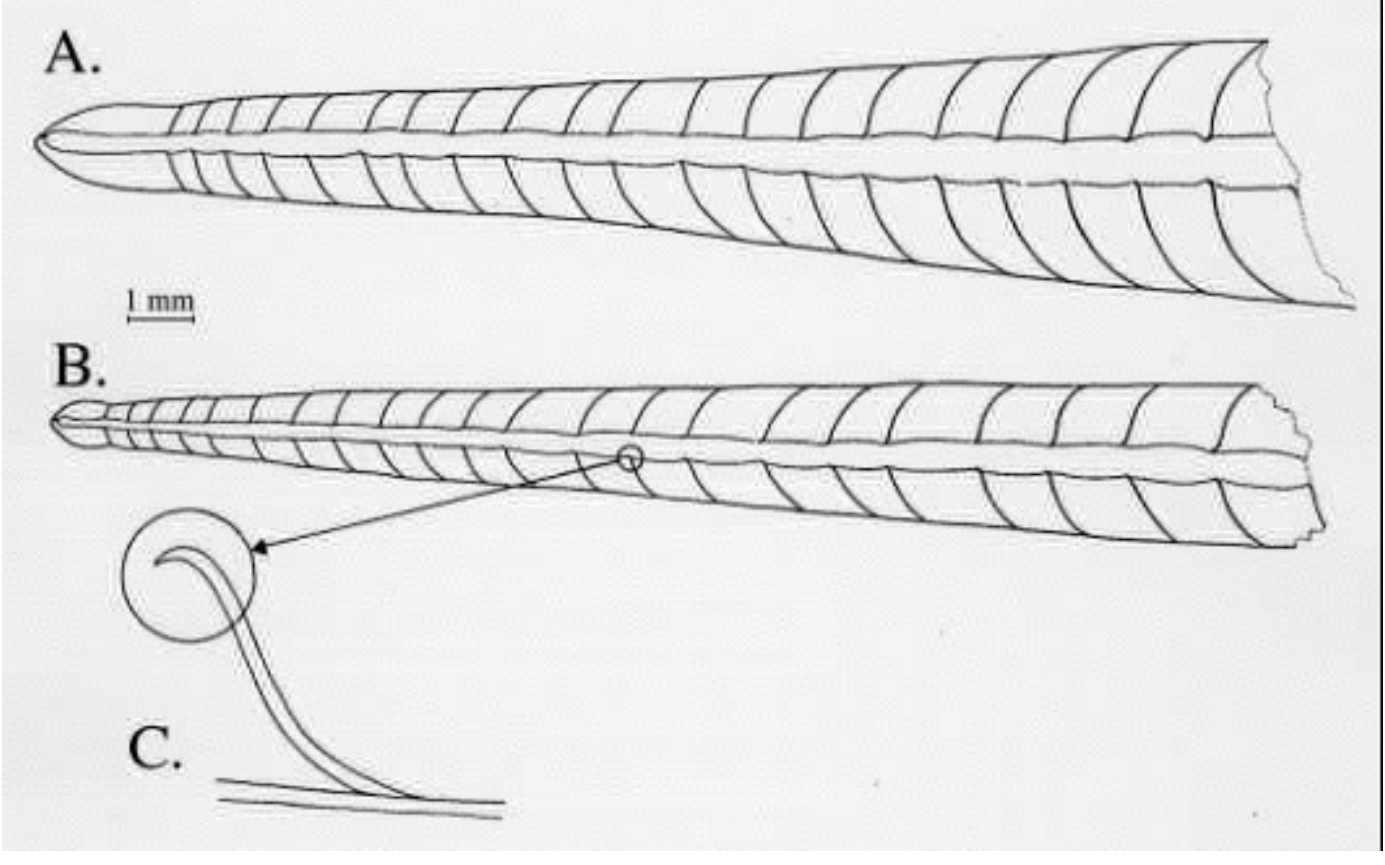

